\title{
Status of Serum Lipids in Individuals with Depression
}

\author{
Saroj Sharma', Lilee Shrestha ${ }^{2}$, Saroj Prasad Ojha ${ }^{3}$, Bharat Jha ${ }^{4}$
}

\begin{abstract}
Affiliations:
'Department of Pathology, Kanti Children's Hospital, Maharajgunj, Kathmandu

${ }^{2}$ National Public Health Laboratory, Teku , Kathmandu

${ }^{3}$ Department of Psychiatry and Mental Health, Institute of Medicine, TUTH

${ }^{4}$ Department of Biochemistry, Institute of Medicine, TUTH
\end{abstract}

Correspondence to:

Saroj Sharma

Medical Technologist

Department of Pathology

Kanti Children's Hospital

Maharajgunj, Kathmandu, Nepal

Email: sarose.sharma30@yahoo.com

How to cite this article:

Sharma S, Shrestha L, Ojha S P, Jha B. Status of Serum Lipids in Individuals with Depression. Ann. Clin. Chem. Lab. Med. 2016:2(1);24-27

DOI: http://dx.doi.org/10.3126/acclm.v2i1.14656

(C) 2016 Nepalese Association for Clinical Chemistry

\section{(c) (1) ()}

This work is licensed under a Creative Commons Attribution-ShareAlike 4.0 International License.

\section{Abstract \\ BACKGROUND}

Epidemiological studies have shown the association between depressive illness with cardiovascular disease (CVD). Serum lipid abnormality is one of the major risk factor for cardiovascular disease. Therefore, this study aimed to access the status of serum lipid in individuals with depression.

\section{METHODS}

A cross sectional study was carried out in Tribhuvan University Teaching Hospital (TUTH) over the period of 16 month from June 2011 to October 2012. A total of 85 individuals with depression and the same number of age-sex matched controls were enrolled in the study. Depression was diagnosed by consultant psychiatrist as per ICD-10-DCR criteria. Serum lipid profile was assessed in both test and control groups after an overnight fasting. A written consent was taken for anthropometric data and sample collection.

\section{RESULTS}

Large numbers of depressive individuals were found to have dyslipidemia. Total cholesterol, triglyceride was found to be significantly higher in test group than in control. The mean HDL-cholesterol was found significantly lower in test group compared to control. No significant differences between test and control were observed in VLDL-cholesterol and LDLcholesterol.

\section{CONCLUSIONS}

Serum lipid profile abnormalities are found high in individuals with depression. Based on the observation of this study, serum lipid abnormalities seen in individuals with depression make them vulnerable to cardiovascular disease.

KEYWORDS: Depression, Serum lipid, Dyslipidemia. 


\section{Introduction}

Epidemiological studies have shown the association between depressive illness with cardiovascular disease (CVD) [1-4]. Serum lipid abnormality is the major risk factor for CVD [5]. The association between the depression and the serum lipid abnormality is poorly understood and there are limited studies done to assess the cardiovascular risk factors in the depressive individuals. Apart from the subjective experiences of people with depression, the impact on social and occupational functioning, physical health and mortality is substantial. There are interrelationships between depression and physical health. The aim of this study was to access the pattern of lipid profile abnormality in Depressive individuals. The study will help in the management of the depressive patient; taking into account the physical health and may guide the need of any lifestyle changes or other medication to help reduce the morbidity and mortality.

\section{Methods}

A cross sectional study was carried out over the period of 16 month from June 2011 to October 2012 in Tribhuvan University Teaching Hospital, Kathmandu. A total of 85 individuals with depression and the same number of age sex matched control were enrolled in the study. Depression was diagnosed by consultant psychiatrist as per ICD-10-DCR guideline [6]. Written consent was taken from both patient and control group. Individuals with preexisting cardiovascular disease were excluded. A questionnaire regarding the demographic parameters was taken. Blood sample was drawn after an overnight fast by standard vein puncture. Blood was allowed to clot in water bath at $37^{\circ} \mathrm{C}$. Blood sample was centrifuged at 2000-3000 rpm for 5 minutes to separate serum. Total cholesterol (TC), HDL-cholesterol (HDL-C) and triglyceride (TG) were analyzed from the serum by enzymatic methods in fully automatic chemistry analyzer BT 3000, Italy. LDLcholesterol (LDL-C) was calculated using Fridewald formula [7]. Laboratory Standard Operating Procedures were followed and internal quality control measures were applied. Chi square test and Student's t test were used for statistical analysis.

\section{Results}

A total of 170 subjects (85 patients and 85 controls) were enrolled in this study. Among them, 47 were male and 38 were female in the depressive group and same number of males and females in the control group. Comparison of qualitative data between cases and control showed significant differences between smoking status, alcohol intake, history of diabetes, hypertension and physical activity. The findings of this study is summarized in Table 1 and 2.

TC, TG was found to be significantly higher in test group compared to control. The mean HDL$\mathrm{C}$ was found significantly lower in test group compared to control. No significant differences between test and control were observed in case of VLDL-cholesterol and LDL-C.

Table 1. Characteristics of qualitative data for case and controls.

\begin{tabular}{|c|c|c|c|c|c|c|c|c|}
\hline \multirow[t]{2}{*}{ Parameter } & & \multicolumn{2}{|c|}{ Case } & \multicolumn{2}{|c|}{ Control } & \multicolumn{2}{|c|}{ Total } & \multirow[t]{2}{*}{$P$ value } \\
\hline & & $\mathrm{n}=85$ & $\%$ & $\mathrm{n}=85$ & $\%$ & $\mathrm{n}=170$ & $\%$ & \\
\hline \multirow{2}{*}{ Sex } & Male & 47 & 55.3 & 47 & 55.3 & 94 & 55.3 & \multirow{2}{*}{1.0} \\
\hline & Female & 38 & 44.7 & 38 & 44.7 & 76 & 44.7 & \\
\hline \multirow{2}{*}{ Smoking } & Yes & 19 & 67.9 & 09 & 32.1 & 28 & 16.5 & \multirow{2}{*}{0.06} \\
\hline & No & 66 & 77.6 & 76 & 89.4 & 142 & 83.5 & \\
\hline \multirow{2}{*}{ Alcohol } & Yes & 23 & 27.1 & 12 & 14.1 & 35 & 20.6 & \multirow{2}{*}{0.05} \\
\hline & No & 62 & 72.9 & 73 & 85.9 & 135 & 79.4 & \\
\hline \multirow{2}{*}{ Diabetes } & Yes & 9 & 10.6 & 0 & 0 & 9 & 8.8 & \multirow{2}{*}{$<0.001$} \\
\hline & No & 76 & 89.4 & 85 & 100 & 161 & 91.2 & \\
\hline \multirow{2}{*}{ Hypertension } & Yes & 18 & 21.2 & 0 & 0 & 18 & 11.6 & \multirow{2}{*}{$<0.001$} \\
\hline & No & 67 & 78.8 & 85 & 100 & 152 & 89.4 & \\
\hline \multirow{2}{*}{ Exercise } & Yes & 6 & 7.1 & 20 & 23.5 & 26 & 15.3 & \multirow{2}{*}{0.005} \\
\hline & No & 79 & 92.9 & 65 & 76.5 & 144 & 84.7 & \\
\hline Family history & Yes & 9 & 10.6 & 12 & 14.1 & 21 & 12.4 & \multirow{2}{*}{0.64} \\
\hline CVD & No & 76 & 89.4 & 73 & 85.9 & 149 & 87.6 & \\
\hline
\end{tabular}


Table 2. Lipid profile of cases and controls. (Data: Mean \pm S.D)

\begin{tabular}{lccc}
\hline Parameter & Cases & Control & p value \\
\hline $\begin{array}{l}\text { TC } \\
(\mathrm{mmol} / \mathrm{l})\end{array}$ & $5.09 \pm 1.15$ & $4.39 \pm 1.05$ & $<0.005$ \\
$\begin{array}{l}\text { HDL-C } \\
(\mathrm{mmol} / \mathrm{l})\end{array}$ & $1.06 \pm 0.24$ & $1.26 \pm 0.25$ & $<0.005$ \\
$\begin{array}{l}\text { VLDL-C } \\
(\mathrm{mmol} / \mathrm{l})\end{array}$ & $0.77 \pm 0.30$ & $0.69 \pm 0.31$ & 0.13 \\
$\begin{array}{l}\mathrm{LDL}-\mathrm{C} \\
(\mathrm{mmol} / \mathrm{l})\end{array}$ & $3.10 \pm 0.93$ & $3.29 \pm 1.06$ & 0.24 \\
$\begin{array}{l}\mathrm{TG} \\
(\mathrm{mmol} / \mathrm{l})\end{array}$ & $1.95 \pm 1.05$ & $1.52 \pm 0.69$ & 0.002 \\
\hline
\end{tabular}

\section{Discussion}

The purpose of this study is to evaluate the serum lipids in depressive individuals. In this study, the mean TC $(5.09 \pm 1.15$ vs $4.39 \pm 1.05 \& \mathrm{p}=<0.001)$, and TG $(1.95 \pm 1.05$ vs $1.52 \pm 0.69 \& \mathrm{p}=0.002)$ values in cases are found significantly higher than that of the control. The difference between the mean of LDL-C between case and control is insignificant. While HDL-C $(1.06 \pm 0.24$ vs $1.26 \pm 0.25 \& \mathrm{p}=<0.001)$ was found significantly lower than that of the control. Similar results have been found by a study in India stating higher total lipids, VLDL-C and TG and lower HDL-C in depressed subjects [8].

Another study in patient with Major Depression Disorder showed higher cholesterol $(197.7 \pm 42.9$ vs. $\quad 176.9 \pm 34.7 \mathrm{mg} / \mathrm{dL}, \quad \mathrm{p}=0.044), \quad \mathrm{TG}$ $(139.5 \pm 92.5$ vs. $91.4 \pm 65.7 \mathrm{mg} / \mathrm{dL}, \mathrm{p}=0.018)$, LDL $(130.0 \pm 33.2$ vs. $106.6 \pm 27.1, \mathrm{p}=0.004)$ level than normal control group [9]. Similar results are found by various other studies [10-12].
In contrast, the study by Chen et al. found lower level of TC compared to control group [13]. Similarly, lower level of TC in depression was also shown by Beigel et al. [14].

A finding of the study by Abdul et al. showed that TC, serum TG and serum LDL-C are decreased while serum HDL-C is increased in depression [15].

The presence of chronic stress among depressed patients is very high. Stress is known to increase the serum cortisol level and consequently mobilizes the fat from the adipose tissue to prepare the body to combat the stress [16]. However, inconsistencies among these various reports appear to suggest that the link between plasma TC and occurrence of depression is less straightforward than it might seem, probably, due to other clinical conditions, nutritional factors or other life style factors that modulate plasma lipids.

\section{Conclusion}

Serum lipid profile abnormalities are found high in individuals with depression. Based on the observation of this study, Serum lipid abnormalities seen in individuals with depression make them vulnerable to cardiovascular disease. The identification of the individuals with high risk for CVD plays crucial role for the declination of the morbidity and mortality in patients with depression. The screening of those patients for these factors regularly is recommended.

\section{Conflict of Interest}

None declared
1. Larson SL, Owens PL, Ford D, Eaton W. Depressive disorder, dysthymia, and risk of stroke: Thirteen-year follow-up from the Baltimore epidemiologic catchment area study. 2001;32:1979-1983

2. Jonas B, Mussolino ME. Symptoms of depression as a prospective risk factor for stroke Psychosom Med 2000;62:463-471

http://dx.doi.org/10.1097/0000684 2-200007000-00001

3. Lauzon C, Beck CA, Huynh T, Dion D, RacineN, Carignan $S$. Depression and prognosis following hospital admission because of acute myocardial infarction CMAJ 2003;168:547-552

4. Mayou RA, Gill D, Thompson DR, Day A, Hicks N. et al. Depression and anxiety as predictors of outcome

\section{REFERENCES}

after myocardial infarction

Psychosom Med 2000;62:212-219 http://dx.doi.org/10.1097/0000684 2-200003000-00011

5. Warburton DE, Nicol CW, Bredin SS. Health benefits of physical activity: the evidence CMAJ 2006;174:801-809 http://dx.doi.org/10.1503/cmaj.051 351

6. World Health Organization (1992).International Classification of Diseases Diagnostic Criteria for Research, 10th Revision (ICD-10DCR). Geneva: WHO.

7. Friedewald WT, Levy RI, Fredrickson DS. Estimation of the concentration of low-density lipoprotein cholesterol in plasma, without use of the preparative ultracentrifuge. Clinical Chemistry 1972;18(6):499-502
8. Gupta R, Solanki RK, Dubey V, Midha PK, Pathak V. Association of lipid profile with depressive features in young hypertensives JPPS 2008;5:101

9. Ahn EJ, Choi JS, Jang YL, Lee HW, Sim HB. Heart Rate Variability and Lipid Profile in Patients with Major Depressive Disorder. Sleep Med Psychophysiol. 2012;19(1):27-34

10. Shizuka K, Yambe T. Relationship between depression and lipid metabolism in the elderly with hypertension. Nippon Ronen Igakka zasshi. 2001;38:785-790

http://dx.doi.org/10.3143/geriatrics. 38.785

11. Kemp BJ, Spungen AM, Adkins RH, Krause JS, Bauman WA. The relationships among serum lipid levels, adiposity, and depressive symptomatology in persons aging 
with spinal cord injury. J Spinal Cord Med. 2000;23(4):216-220

12. Gary T L, Crum RM, CooperPatrick L, Ford D, Brancati FL. Depressive symptoms and metabolic control in African-Americans with type 2 diabetes. January 2000;23 (1):23-29 http://dx.doi.org/10.2337/diacare.23 .1 .23

13. Chen CC, Lu FH, Wu JS, Chang C J. Correlation between serum lipid concentrations and psychological distress. Psych. Res. 2001;102:153162.

http://dx.doi.org/10.1016/s01651781(01)00231-1

14. Beigel Y, Peleg A, Assali A, Nachshon I. Effects of hypocholesterolemic dietary and drug therapy on measures of dysphoric emotions, Eur Psychiatry. 1998;13(6):288-94.

http://dx.doi.org/10.1016/S09249338(98)80046-1
15. Khalid A, Lal N, Trivedi JK, Dalal PK, Asthana OP, Srivastava JS. Serum lipids: New Biological marker of depression? 1998;40(3):217-223.

16. Berne C, Bjornetorp P. The metabolic syndrome. In: Stress in health and disease. Arnetz BB, Ekman R (Eds). Wiley India Pvt Ltd, New Delhi; 2006:317-32. http://dx.doi.org/10.1002/3527609 156.ch19 